\title{
The Growth of Gypsum in the Presence of Hexavalent Chromium: A Multiscale Study
}

\author{
Juan Morales ${ }^{1}$, José Manuel Astilleros ${ }^{2,3, *}$, Emilio Matesanz ${ }^{4}$ and Lurdes Fernández-Díaz ${ }^{2,3}$ \\ 1 Laboratorio de Estudios Cristalográficos, Instituto Andaluz de Ciencias de la Tierra, \\ Consejo Superior de Investigaciones Científicas, Universidad de Granada (CSIC, UGR), \\ Avenida de las Palmeras 4, E-18100 Armilla, Granada, Spain; juan.morales@csic.es \\ 2 Departamento de Cristalografía y Mineralogía, Universidad Complutense de Madrid, \\ C/José Antonio Novais 2, E-28040 Madrid, Spain; lfdiaz@geo.ucm.es \\ 3 Instituto de Geociencias, Consejo Superior de Investigaciones Científicas, \\ Universidad Complutense de Madrid (CSIC, UCM), C/José Antonio Novais 2, E-28040 Madrid, Spain \\ 4 Centro de Asistencia a la Investigación de Difracción de Rayos X, Universidad Complutense de Madrid, \\ E-28040 Madrid, Spain; ematesanz@quim.ucm.es \\ * Correspondence: jmastill@ucm.es; Tel.: +34-913-944-876 \\ Academic Editor: Athanasios Godelitsas \\ Received: 12 January 2016; Accepted: 8 March 2016; Published: 15 March 2016
}

\begin{abstract}
The sorption of dissolved inorganic pollutants into the structure of minerals is an important process that controls the mobility and fate of these pollutants in the Earth's crust. It also modifies the surface structure and composition of the host mineral, affecting its crystallization kinetics. Here, we investigate the effect of hexavalent chromium, $\mathrm{Cr}(\mathrm{VI})$, on the nucleation and growth of gypsum by conducting two types of experiments: (i) in situ atomic force microscopy (AFM) observations of the growth of gypsum $\{010\}$ surfaces in the presence of $\mathrm{Cr}(\mathrm{VI})$ and (ii) gypsum precipitation experiments by mixing aqueous solutions containing variable amounts of $\mathrm{Cr}(\mathrm{VI})$. Gypsum precipitation is progressively delayed when occurring from solutions bearing increasing $\mathrm{Cr}(\mathrm{VI})$ concentrations. Chemical analyses of gypsum precipitates show that gypsum incorporates small $\mathrm{Cr}(\mathrm{VI})$ amounts that correlate with the content of this ion in the aqueous solution. Gypsum cell parameters variation reflects this incorporation. At the molecular scale, $\mathrm{Cr}(\mathrm{VI})$ induces a slowdown of step advance rates on gypsum $\{010\}$ surfaces accompanied by the roughening of nanostep edges and the so-called "template effect". This effect involves the reproduction of the original nanotopography after the completion of individual advancing monolayers and appears as a general nanoscale phenomenon occurring during growth of solid solutions from aqueous solutions even in the case of compositionally-restricted solid solutions.
\end{abstract}

Keywords: hexavalent chromium; gypsum; atomic force microscopy; crystal growth; nucleation; mineral surfaces; template effect

\section{Introduction}

There are numerous examples of crystal surfaces undergoing changes of nanotopographic features during growth from aqueous solutions containing foreign ions [1-7]. One of the most remarkable phenomena is the so-called "template effect", which was first defined by Astilleros [8] to describe the reproduction of the original nanotopography of a crystal surface, including etch-pits and step edges, after successive completion of advancing monolayers. This effect has been interpreted as the result of the incorporation of the foreign ions in the growing layers during step advancement. The difference between the ionic radii of the substituted ions induces lattice mismatch between the new doped layer and the original substrate (free of impurities), which in turn causes elastic strain and stress. 
Subsequently, relaxation of this elastic stress occurs perpendicular to the layer, thereby introducing local variations in bond lengths. This, in turn, results in the roughing of the surface of the monolayer. This phenomenon is reflected by the characteristics of the advancement of successive monolayers on the original cleaved surface. Since the surface of successive monolayers is progressively rougher, their advancement also occurs at a progressively lower rate and eventually stops after a certain number of monolayers have piled up $[2,8]$.

The template effect has been reported in varied systems as $\mathrm{CaCO}_{3}-\mathrm{Me}^{2+}-\mathrm{H}_{2} \mathrm{O}(\mathrm{Me}=\mathrm{Sr}, \mathrm{Mn}, \mathrm{Mg}$, $\mathrm{Co}), \mathrm{CaMg}\left(\mathrm{CO}_{3}\right)_{2}-\mathrm{H}_{2} \mathrm{O} ; \mathrm{BaSO}_{4}-\mathrm{Sr}^{2+}-\mathrm{H}_{2} \mathrm{O}$ or $\mathrm{BaSO}_{4}-\mathrm{CO}_{3}{ }^{2-}-\mathrm{H}_{2} \mathrm{O}$. In all cases, a slight lattice misfit through the interface between the original surface and the first growing monolayer is assumed. Most examples of the template effect correspond to systems where the compositional variation involves the substitution of cations [8-12]. However, several examples of this phenomenon occurring during the growth of anionic solid solutions have also been reported [3,13,14].

Chromium $(\mathrm{Cr})$ is a most strategic element due to its use in numerous and important industrial procedures [15]. These industrial applications have determined significant increases of the concentration of $\mathrm{Cr}$ in certain settlements with important environmental consequences. Indeed, the hexavalent form of this element, $\mathrm{Cr}(\mathrm{VI})$, is highly toxic and can poison most organisms even at low degrees of exposure [15]. Moreover, $\mathrm{Cr}(\mathrm{VI})$ also is very soluble and, consequently, highly mobile. Thus, it is not surprising that the pollution of soil and ground waters by $\mathrm{Cr}(\mathrm{VI})$ is an important public health concern. Because under circumneutral to basic $\mathrm{pHs} \mathrm{CrO}_{4}{ }^{2-}$ is the most stable anion of $\mathrm{Cr}(\mathrm{VI})$, in most cases the remediation of $\mathrm{Cr}(\mathrm{VI})$-related contamination can be achieved through the removal $\mathrm{CrO}_{4}{ }^{2-}$ anions. $\mathrm{CrO}_{4}{ }^{2-}$-sorption on mineral surfaces can be an efficient method for this removal. Since the similarity of $\mathrm{CrO}_{4}{ }^{2-}$ and $\mathrm{SO}_{4}{ }^{2-}$ in both size and geometry permits the isomorphic substitution of these oxyanions in mineral structures, sulfate minerals are especially suitable phases for uptaking $\mathrm{CrO}_{4}{ }^{2-}$ and reducing its bioavailability in the environment through the formation of solid solutions.

Here, we study the nanoscale characteristics of gypsum $\{010\}$ growth in the presence of different concentrations of $\mathrm{Cr}(\mathrm{VI})$, aiming to confirm the template effect as a nanoscale phenomenon inherent to crystal growth in solid solution-aqueous solution systems. We also aim to study the capacity of gypsum to sequester $\mathrm{Cr}(\mathrm{VI})$. In order to achieve these goals, we conducted in situ crystal growth observations using atomic force microscopy (AFM) and direct precipitation experiments. The samples obtained from direct precipitation experiments were characterized using inductively coupled plasma-optical emission spectrometry (ICP-OES, SPECTRO Analytical Instruments, Kleve, Germany), X-ray diffraction (XRD, Panalytical B.V., Almelo, The Netherlands) and scanning electron microscopy (SEM JEOL Ltd., Tokyo, Japan).

\section{Material and Methods}

In order to study the growth of gypsum in the presence of $\mathrm{Cr}(\mathrm{VI})$, we conducted (i) nanoscale experiments of the growth of $\{010\}$ gypsum surfaces using a Digital Instrument Multimode IIIA AFM (Veeco, Santa Barbara, CA, USA) and (ii) precipitation experiments by mixing solutions. Stock solutions of $\mathrm{CaCl}_{2}, \mathrm{Na}_{2} \mathrm{SO}_{4}$ and $\mathrm{Na}_{2} \mathrm{CrO}_{4}$ were prepared by the addition of reagent-grade compounds (Sigma Aldrich, St. Louis, MO, USA) to high-purity deionized water (resistivity = $18.2 \mathrm{M} \Omega \cdot \mathrm{cm}$ ).

The supersaturation of the aqueous solutions with respect to gypsum was calculated by using the expression:

$$
\beta_{\mathrm{Gp}}=a\left(\mathrm{Ca}^{2+}\right) \cdot a\left(\mathrm{SO}_{4}{ }^{2-}\right) \cdot\left[a\left(\mathrm{H}_{2} \mathrm{O}\right)\right]^{2} / \mathrm{K}_{\mathrm{sp}, \mathrm{Gp}}
$$

where $a\left(\mathrm{Ca}^{2+}\right), a\left(\mathrm{SO}_{4}{ }^{2-}\right)$ and $a\left(\mathrm{H}_{2} \mathrm{O}\right)$ are the respective activities of calcium, sulfate and water in the aqueous solution and $\mathrm{K}_{\mathrm{sp}, \mathrm{Gp}}$ is the thermodynamic solubility product of gypsum $\left(\mathrm{K}_{\mathrm{sp}, \mathrm{Gp}}=10^{-4.85}\right.$ at $25^{\circ} \mathrm{C}$; "minteq" database [16]). The solution is in equilibrium with respect to gypsum when $\beta_{\mathrm{Gp}}=1$, while $\beta_{\mathrm{Gp}}>1$ and $\beta_{\mathrm{Gp}}<1$ indicate that the solution is supersaturated and undersaturated, respectively. In all cases, the activities and supersaturation degrees were calculated by using the numerical code PHREEQC [16]. 
Other possible solid phases, such as chromatite $\left(\mathrm{CaCrO}_{4}\right)$ or calcium chromate dihydrate $\left(\mathrm{CaCrO}_{4} \cdot 2 \mathrm{H}_{2} \mathrm{O}\right)$, were not taken into consideration due to the very high solubilities of these phases [17]. All the experiments were conducted at $25^{\circ} \mathrm{C}$ and atmospheric pressure.

\subsection{In Situ AFM Observations}

In situ observations of the growth of gypsum $\{010\}$ surfaces in contact with solutions supersaturated with respect to this phase and bearing different amounts of $\mathrm{CrO}_{4}{ }^{2-}$ were conducted using a Digital Instrument Multimode AFM equipped with a fluid cell and working in contact mode. Silicon nitride tips (Veeco NP-S10, Bruker, Camarillo, CA, USA) with a nominal force constant $\mathrm{k}=0.06-0.58 \mathrm{~N} / \mathrm{m}$ were used.

Gypsum has perfect cleavage along $\{010\}$, which is the most common crystallographic form in its habit [18]. Freshly cleaved fragments of natural, optically clear gypsum from Toledo (Spain) (size $\sim 3 \times 3 \times 2 \mathrm{~mm}^{3}$ ) were placed within the fluid cell. In all the cases and prior to the experiment, a solution undersaturated with respect to gypsum $\left(\beta_{\mathrm{Gp}}=0.8\right)$ was passed over the cleaved surface to ensure its cleaning and slight dissolution. Crystallographic directions on the gypsum surface were established on the basis of its dissolution features [19]. The aqueous solutions were prepared from stock solutions immediately before being injected in the fluid cell.

Kinetic information was obtained from measurements of advancement of [001] and [102] steps, which are the most stable ones on gypsum $\{010\}$ surfaces. Table 1 list the concentration of reactants used in the experiments $\left(\mathrm{Ca}^{2+}, \mathrm{Na}^{+}, \mathrm{Cl}^{-}, \mathrm{SO}_{4}{ }^{2-}\right.$ and $\left.\mathrm{CrO}_{4}{ }^{2-}\right)$ and the respective supersaturation values. In all cases, the experiments were carried out varying the concentration of chromate in solution and keeping a relatively constant supersaturation value $\left(\beta_{\mathrm{Gp}} \approx 1.35\right)$. In addition, some experiments using more concentrated and supersaturated solutions $\left(\left[\mathrm{CrO}_{4}{ }^{2-}\right]=0.075 \mathrm{M}, \beta_{\mathrm{Gp}} \approx 2.4\right)$ were specifically conducted in order to enhance the effect of $\mathrm{Cr}(\mathrm{VI})$ on the growth process and, in this way, to clearly elucidate the inhibitory mechanism operating in this system. Special attention was paid to changes in the growth rate and morphology of the first layers.

Table 1. Concentrations and supersaturation values of the solutions used in the AFM experiments.

\begin{tabular}{ccccccc}
\hline Exp. Id. & $\begin{array}{c}{\left[\mathrm{CrO}_{4}{ }^{2-}\right]} \\
(\mathbf{m o l} / \mathbf{L})\end{array}$ & $\begin{array}{c}{\left[\mathrm{SO}_{4}{ }^{2-}\right]} \\
(\mathbf{m o l} / \mathbf{L})\end{array}$ & $\begin{array}{c}{\left[\mathrm{Ca}^{2+}\right]} \\
(\mathbf{m o l} / \mathbf{L})\end{array}$ & $\begin{array}{c}{\left[\mathrm{Cl}^{-}\right]} \\
(\mathbf{m o l} / \mathbf{L})\end{array}$ & $\begin{array}{c}{\left[\mathbf{N a}^{+}\right]} \\
(\mathbf{m o l} / \mathbf{L})\end{array}$ & $\beta_{\mathbf{G p}}$ \\
\hline AFM-1 & 0.000 & 0.024 & 0.024 & 0.049 & 0.049 & 1.363 \\
AFM-2 & 0.005 & 0.025 & 0.025 & 0.050 & 0.060 & 1.356 \\
AFM-3 & 0.010 & 0.026 & 0.026 & 0.052 & 0.072 & 1.357 \\
AFM-4 & 0.015 & 0.027 & 0.027 & 0.053 & 0.083 & 1.364 \\
AFM-5 & 0.020 & 0.027 & 0.027 & 0.054 & 0.094 & 1.362 \\
AFM-6 & 0.025 & 0.028 & 0.028 & 0.055 & 0.105 & 1.364 \\
\hline
\end{tabular}

\subsection{Precipitation Experiments}

In addition, sets of experiments were performed by mixing $50 \mathrm{~mL}$ of two equi-molar solutions, one of $\mathrm{CaCl}_{2}$ and the other of $\mathrm{Na}_{2} \mathrm{SO}_{4}$ in $100 \mathrm{~mL}$ polypropylene vessels. The latter solution contained amounts of $\mathrm{Na}_{2} \mathrm{CrO}_{4}$ ranging from 0.01 to $1 \mathrm{M}$. The vessels were immediately sealed after mixing and the solutions were kept at $25^{\circ} \mathrm{C}$ and constantly stirred (200 rpm). Each experiment took one hour. In all the cases, the initial supersaturation with respect to gypsum was adjusted to a similar value $\left(\beta_{\mathrm{Gp}} \approx 47\right)$, irrespective of the amount of $\mathrm{Na}_{2} \mathrm{CrO}_{4}$ in the solution. Three replicates of each experiment were conducted.

Once the solutions of $\mathrm{CaCl}_{2}$ and $\mathrm{Na}_{2} \mathrm{SO}_{4}\left(+\mathrm{Na}_{2} \mathrm{CrO}_{4}\right)$ were mixed, the induction period for nucleation $\left(t_{\mathrm{w}}\right)$ was determined. This parameter can be defined as the time elapsed between the onset of supersaturation and the first changes in the physical properties of the system due to the formation of a solid phase [20]. $t_{\mathrm{w}}$ was determined by visually detecting the appearance of turbidity in the bulk of the solution. Although this method commonly yields slightly longer $t_{\mathrm{w}}$ than more sophisticated 
detection methods, such as conductivity measurements, its accuracy is sufficient for the purposes of this work. Indeed, early classical papers on nucleation kinetics concluded that in the case of nucleation in bulk solution, optical methods and conductivity methods yielded values not significantly different when $t_{w}$ values were longer than $10 \mathrm{~s}$ (see, for example, [21]). After one hour, solid phases were collected by filtering the solution through a $0.45-\mu \mathrm{m}$ Millipore membrane under reduced pressure with a vacuum filtration system, washed twice with Milli-Q water and dried at $40^{\circ} \mathrm{C}$. After $24 \mathrm{~h}$, the solids were weighed and prepared for analysis.

In order to investigate the possible incorporation of chromate in the precipitates, they were dissolved in Milli-Q water and analyzed by ICP-OES, Model Spectro Arcos.

X-Ray diffraction (XRD) analyses were carried out in reflection mode by using a Panalytical $X^{\prime}$ Pert PRO MPD Alfa1 diffractometer (Panalytical B.V., Almelo, The Netherlands) with $\mathrm{Cu} \mathrm{K} \alpha$ radiation $(\lambda=1.54056 \AA)$ from a Ge (111) primary beam monochromator and a fast $X^{\prime}$ Celerator detector. Diffractograms were acquired in continuous-scan mode with 50-s preset time and steps of $0.0084^{\circ}$. X-ray source conditions were $45 \mathrm{kV}$ and $40 \mathrm{~mA}$ with $2200 \mathrm{~W}$ of power. Phase identification was done by means of X'Pert HighScore Plus (Panalytical B.V. software) in combination with ICDD PDF-4 database (International Center for Diffraction Data, Swarthmore, PA, USA). In addition, profile-matching refinement of the profile was done to study the possible variation of cell parameters due to the incorporation of chromate into the crystal structure. The lattice parameters were refined as monoclinic by the Le Bail method [22] using FullProf software [23]. Refinements were started using the $A 2 / a$ space group and structure parameters derived from Comodi et al. [24]. Calculations were firstly performed for blank samples (grown in the absence of chromate) and the resulting data were used as starting point for subsequent refinements. In all cases, the background was fitted with a polynomial function with 6 coefficients, and peak shapes were modeled by means of a standard Thompson-Cox-Hasting pseudo-Voigt function [25] modified to incorporate asymmetry from axial divergence [26]. After several cycles of least-squares minimizations, the profile fitting converged to $R_{p}<14, R_{w p}<24$ and $x^{2}<2.4$.

Selected samples of the precipitates were dried and coated with a thin Au layer for further observation by means of field emission scanning electron microscopy (FE-SEM; JSM-6335F, JEOL Ltd., Tokyo, Japan). Images of the gypsum particles were taken at $15 \mathrm{kV}$ accelerating voltage.

\section{Results}

\subsection{AFM Observations}

The dissolution of gypsum $\{010\}$ surfaces is characterized by the retreat of the pre-existing cleavage steps and by the rapid formation and coalescence of etch pits of $\sim 7.5 \AA$ height, corresponding to the dimensions of half the $b$-axis periodicity of gypsum. These etch pits show a characteristic shape, controlled by the retreat movement of [001] and [101] steps (Figure 1). The features and the orientation of the etch pits enable the definition of the main crystallographic directions on gypsum $\{010\}$ surfaces.

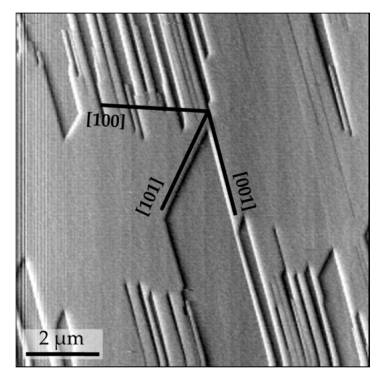

Figure 1. AFM image of a gypsum (010) surface dissolving in an undersaturated solution $\left(\beta_{\mathrm{Gp}}=0.8\right)$. Etch pits are oriented parallel to [001] and [101] and are $\sim 7.5 \AA$ in depth, which corresponds to the dimensions of half the $b$-axis periodicity of gypsum. 
Figure 2 shows an AFM sequence obtained after first injecting a supersaturated $\left(\beta_{G p}=1.36\right)$ chromate-free aqueous solution (Figure 2a) and then a chromate-bearing aqueous solution (Figure 2b,c). The growth on the $\{010\}$ surface of gypsum from chromate-free aqueous solutions (AFM-1) is dominated by the straight advancement of steps [001] and [102] [27] and exhibits an anisotropic behavior, with steps parallel to [102] spreading much faster $(76.2 \pm 24.7 \mathrm{~nm} / \mathrm{s})$ than steps parallel to [001] $(43.7 \pm 12.5 \mathrm{~nm} / \mathrm{s})$. However, when small amounts of $\mathrm{Na}_{2} \mathrm{CrO}_{4}\left(0.025 \mathrm{~mol} / \mathrm{dm}^{-3}\right)$ are added to the solution, (AFM-6) steps become rougher and their advancement rate speeds down. Step rate measurements as a function of $\left(\left[\mathrm{CrO}_{4}{ }^{2-}\right]_{\mathrm{aq}}\right)$ for a given supersaturation $\left(\beta_{\mathrm{Gp}} \approx 1.35\right)$ are shown in Figure 3. As can be observed, growth becomes less anisotropic and the step advancement rate decreases as $\left[\mathrm{CrO}_{4}{ }^{2-}\right]_{\text {aq }}$ increases. However, a complete stoppage of the growth is never attained.
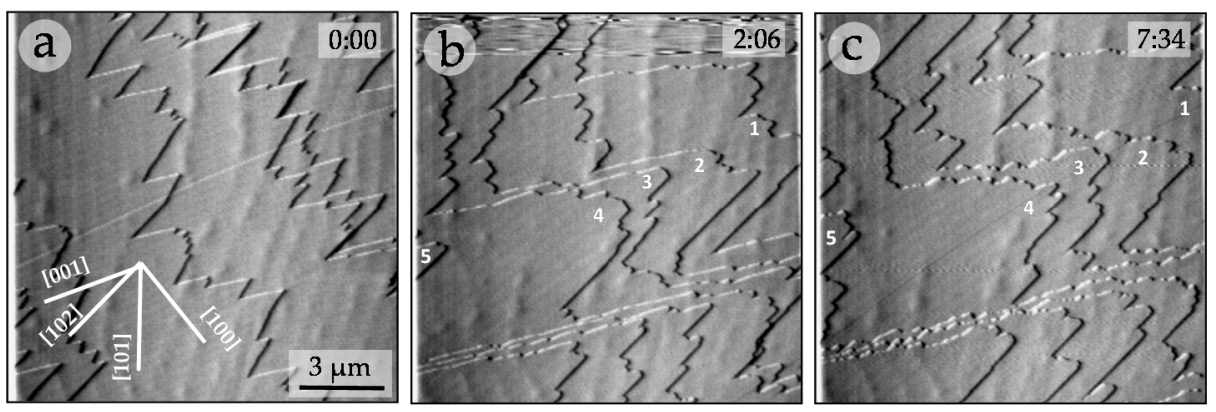

Figure 2. AFM sequence showing the growth of gypsum (010) surface in the presence of $\mathrm{CrO}_{4}{ }^{2-}$ $\left(\left[\mathrm{CrO}_{4}{ }^{2-}\right]=0.025 \mathrm{M} ; \beta_{\mathrm{Gp}}=1.35\right)$. Elapsed times (minutes and seconds) are shown in the upper right-hand corner of each image. It becomes evident that the presence of $\mathrm{CrO}_{4}{ }^{2-}$ in the aqueous solution (b-c) inhibits the step advancement, whereas those steps that can be distinguished in (a) are gone in (b) with about 2 min elapsed between these two images; those steps marked 1-5 in (b) can still be easily distinguished in (c), which elapses over $5 \mathrm{~min}$ with respect to (b).

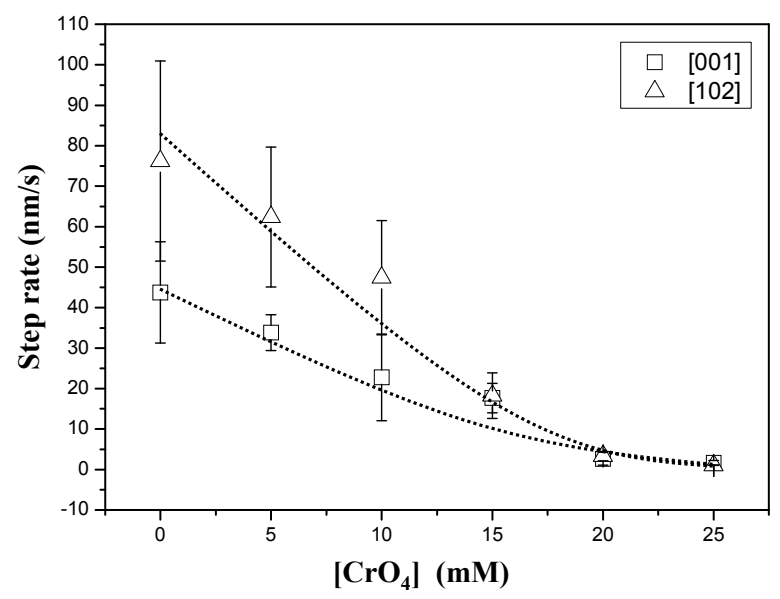

Figure 3. Step advancement rate measurements as a function of $\left[\mathrm{CrO}_{4}{ }^{2-}\right]_{\mathrm{aq}}$ for a constant supersaturation value $\left(\beta_{\mathrm{Gp}} \approx 1.35\right)$.

In order to elucidate the possible effect on the growth process of the new surfaces generated during the experiments, we observed the behavior of the first steps seconds after injecting the solution using more supersaturated and concentrated aqueous solutions $\left(\beta_{\mathrm{Gp}}=2.36 ;\left[\mathrm{CrO}_{4}{ }^{2-}\right]_{\mathrm{aq}}=0.075 \mathrm{M}\right)$. Figure 4 shows the surface of gypsum in contact with an undersaturated aqueous solution (Figure $4 \mathrm{a}$ ) and just after injecting the growing solution (Figure $4 \mathrm{~b}-\mathrm{d}$ ). When the step advancement occurs on the original pure-gypsum substrate, [001] and [101] step edges formed as a result of the initial dissolution of the surface remain straight. However, these steps roughen and become jagged when 
their advancement occurs on a surface formed during the experiment. Moreover, steps growing on the original surfaces grow much faster than those growing on the newly formed layers. Thus, as can be seen by comparing images $4 \mathrm{a}$ and $4 \mathrm{~b}$. The first monolayer (labeled 1 ) rapidly spreads on the original substrate (labeled 0 ) to reach a macro-step (step edge marked by a white solid line) in less than $45 \mathrm{~s}$ (compare images $4 \mathrm{a}$ and $4 \mathrm{~b}$ ). Images in Figure $4 \mathrm{~b}-\mathrm{d}$ show that the second monolayer (labeled 2) spreads on the first monolayer (1). However, this second monolayer moves at a much lower rate than the first monolayer did on the original substrate. As a result, after over $11 \mathrm{~min}$, monolayer 2 still has not reached the macro-step. Similarly, the distance between subsequent step edges, which bound successive monolayers (marked by black numbers $1^{\prime}-3^{\prime}$ ), becomes progressively larger. This can only be explained by a progressive reduction of the rate at which successive monolayers spread. Moreover, the inhibitory effect of chromate on gypsum growth results in the reproduction of some features of the original microtopography (see black dashed lines in Figure 4a,c).
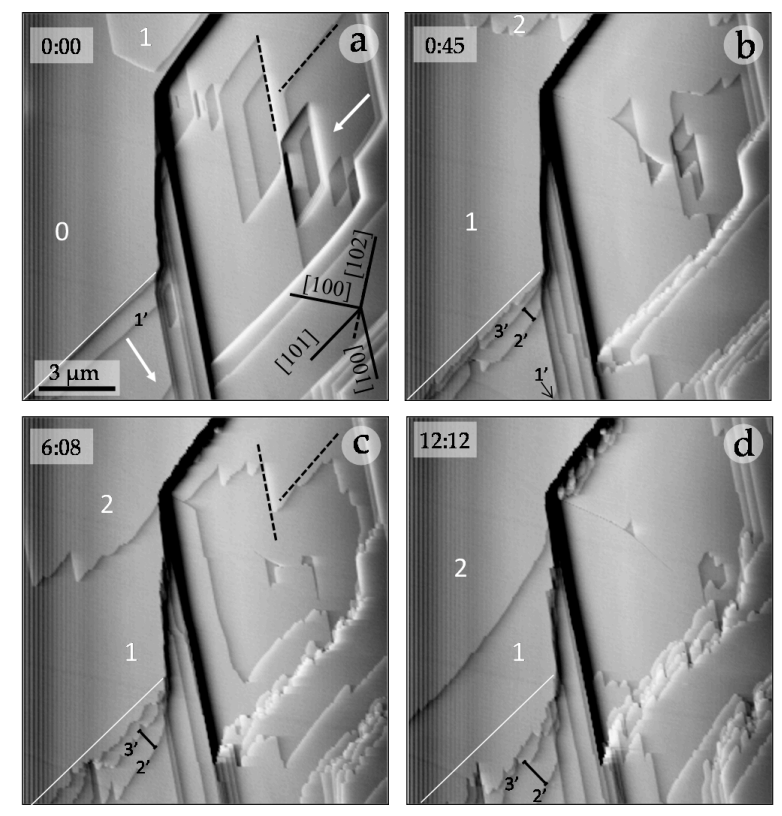

Figure 4. Growth sequence on gypsum (010) surface in the presence of chromate $\left(\left[\mathrm{CrO}_{4}{ }^{2-}\right]_{\mathrm{aq}}=0.075 \mathrm{M}\right.$; $\left.\beta_{\mathrm{Gp}}=2.36\right)$. Elapsed times are shown in the upper left-hand corner of each image. Black-dashed lines (in pictures a and c) indicate step edges of the original topography and its reproduction by the advancement of the subsequent monolayer. White arrows (in picture a) indicate the movement directions of some steps. White numbers correspond to the original substrate (0) and the first (1) and the second (2) monolayers. The solid white line in a-d indicates the original position of a macro-step. The black numbers mark the edge of steps that bound the first ( $\left.1^{\prime}\right)$, second ( $\left.2^{\prime}\right)$ and third ( $\left.3^{\prime}\right)$ monolayers. Steps growing on the original substrate remain straight during their advancement and grow faster than those growing on layers formed during the experiment, which become jagged. The first monolayer (1) reaches the macrostep in less than $45 \mathrm{~s}($ see $(\mathbf{a}, \mathbf{b}))$. The slower advance of monolayer 2 determines that it still has to reach this macro-step after advancing during $11 \mathrm{~min}$ (see images (b-d)). Note how the distance between steps $2^{\prime}$ and $3^{\prime}$ (lower left-hand corner in images $\mathbf{b}-\mathbf{d}$ ) progressively increases. This indicates that the third monolayer advances at a slower rate than the second monolayer, evidencing a cumulative inhibitory effect on the growth of successive monolayers.

\subsection{Precipitation of Gypsum in the Presence of $\mathrm{CrO}_{4}{ }^{2-}$}

Precipitation experiments have shown that $t_{\mathrm{w}}$ strongly depends on $\left[\mathrm{CrO}_{4}{ }^{2-}\right]_{\mathrm{aq}}$. In the absence of chromate (blank experiment) the bulk solution becomes whitish very rapidly after the mixing of the reactive solutions $\left(t_{\mathrm{w}} \approx 10 \mathrm{~s}\right)$. In contrast, in those experiments conducted in the presence of $\mathrm{CrO}_{4}{ }^{2-}$, the turbidity appears later as $\left[\mathrm{CrO}_{4}{ }^{2-}\right]_{\mathrm{aq}}$ increases $\left(\mathrm{t}_{\mathrm{w}} \approx 150 \mathrm{~s}\right.$ for $\left.\left[\mathrm{CrO}_{4}{ }^{2-}\right]_{\mathrm{aq}}=1 \mathrm{M}\right)$ 
and follows an exponential trend (see Table 2). Moreover, the amount of precipitate recovered from the vessels progressively decreases as $\left[\mathrm{CrO}_{4}{ }^{2-}\right]_{\mathrm{aq}}$ increases. For instance, the precipitate recovered in the experiments conducted under the higher $\left[\mathrm{CrO}_{4}{ }^{2-}\right]_{\mathrm{aq}}(1.0 \mathrm{M})$ weighs approximately half the weight of the precipitate recovered in the blank experiments. The color of the precipitate also changes with the $\left[\mathrm{CrO}_{4}{ }^{2-}\right]_{\mathrm{aq}}$, evolving from white in the blank experiment to progressively darker yellow as $\left[\mathrm{CrO}_{4}^{2-}\right]_{\mathrm{aq}}$ increases.

Table 2. Concentrations, supersaturation values, induction time for nucleation $\left(t_{\mathrm{w}}\right)$ and weight of the recovered solids in the direct precipitation (DP) experiments.

\begin{tabular}{ccccccccc}
\hline Exp. Id. & $\begin{array}{c}{\left[\mathrm{CrO}_{4}{ }^{2-}\right]} \\
(\mathbf{m o l} / \mathbf{L})\end{array}$ & $\begin{array}{c}{\left[\mathbf{S O}_{\mathbf{4}}{ }^{2-}\right]} \\
(\mathbf{m o l} / \mathbf{L})\end{array}$ & $\begin{array}{c}{\left[\mathrm{Ca}^{2+}\right]} \\
(\mathbf{m o l} / \mathbf{L})\end{array}$ & $\begin{array}{c}{\left[\mathbf{C l}^{-}\right]} \\
(\mathbf{m o l} / \mathbf{L})\end{array}$ & $\begin{array}{c}{\left[\mathbf{N a}^{+}\right]} \\
(\mathbf{m o l} / \mathbf{L})\end{array}$ & $\beta_{\mathrm{Gp}}$ & $\mathbf{t}_{\mathbf{w}}(\mathbf{s})$ & Weight (g) \\
\hline DP-1 & 0.00 & 0.26 & 0.26 & 0.52 & 0.52 & 47.6 & $8.7 \pm 2.3$ & $4.08 \pm 0.02$ \\
DP-2 & 0.01 & 0.26 & 0.26 & 0.52 & 0.54 & 47.6 & $9.3 \pm 2.5$ & $4.04 \pm 0.05$ \\
DP-3 & 0.03 & 0.26 & 0.26 & 0.52 & 0.58 & 47.6 & $10.3 \pm 3.2$ & $4.05 \pm 0.03$ \\
DP-4 & 0.06 & 0.26 & 0.26 & 0.52 & 0.64 & 47.6 & $12.0 \pm 2.6$ & $4.03 \pm 0.07$ \\
DP-5 & 0.10 & 0.26 & 0.26 & 0.52 & 0.72 & 47.3 & $16.3 \pm 3.0$ & $3.99 \pm 0.07$ \\
DP-6 & 0.20 & 0.26 & 0.26 & 0.52 & 0.92 & 47.3 & $25.0 \pm 3.6$ & $3.81 \pm 0.04$ \\
DP-7 & 0.40 & 0.25 & 0.25 & 0.51 & 1.31 & 46.2 & $40.7 \pm 6.0$ & $3.47 \pm 0.05$ \\
DP-8 & 0.60 & 0.25 & 0.25 & 0.50 & 1.70 & 47.3 & $60.0 \pm 5.0$ & $3.27 \pm 0.04$ \\
DP-9 & 0.80 & 0.25 & 0.25 & 0.49 & 2.09 & 47.6 & $92.0 \pm 3.0$ & $2.85 \pm 0.13$ \\
DP-10 & 1.00 & 0.24 & 0.24 & 0.48 & 2.48 & 47.6 & $150.0 \pm 8.2$ & $2.44 \pm 0.08$ \\
\hline
\end{tabular}

Selected precipitates were chemically analyzed by ICP-OES. Figure 5 shows the molar concentration of $\mathrm{Ca}, \mathrm{S}$ and $\mathrm{Cr}$ in the solid samples $\left([\mathrm{Ca}]_{\mathrm{s}},[\mathrm{S}]_{\mathrm{s}}\right.$ and $\left.[\mathrm{Cr}]_{\mathrm{S}}\right)$. These results show that: (a) all the precipitates analyzed contain $\mathrm{Cr}$ and; (b) a direct correlation between $\left[\mathrm{CrO}_{4}{ }^{2-}\right]_{\mathrm{aq}}$ and $[\mathrm{Cr}]_{\mathrm{s}}$ can be established. Moreover, it is interesting to note that whereas $[\mathrm{Ca}]_{s}$ keeps an approximately constant value, $[\mathrm{S}]_{\mathrm{S}}$ and $[\mathrm{Cr}]_{\mathrm{S}}$ follow an opposite trend: i.e., $[\mathrm{S}]_{\mathrm{S}}$ decreases by the same amount as $[\mathrm{Cr}]_{S}$ increases $\left([\mathrm{S}]_{\mathrm{S}}+[\mathrm{Cr}]_{\mathrm{S}}=\right.$ constant $)$.

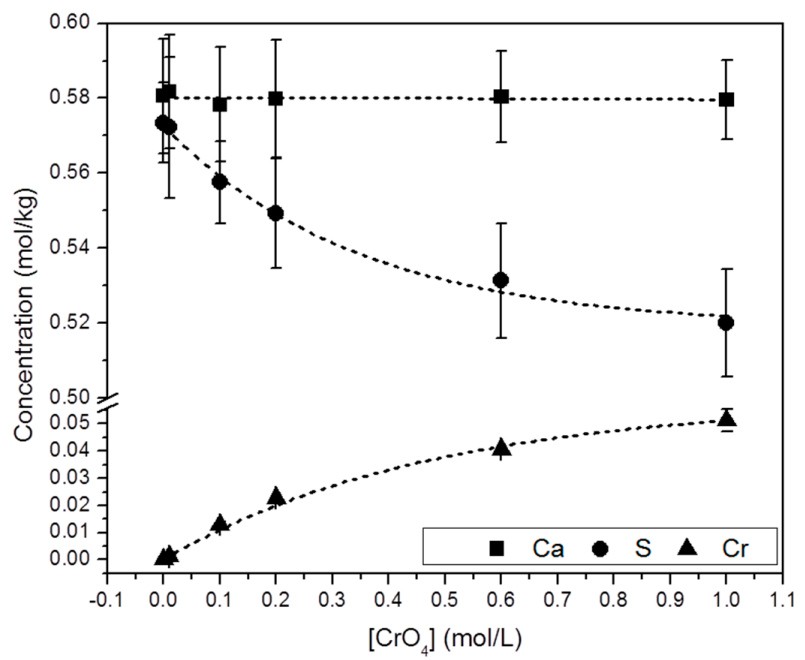

Figure 5. Chemical composition (from ICP-OES analyses) of solid samples collected from the precipitation experiments as a function of $\left[\mathrm{CrO}_{4}{ }^{2-}\right]_{\mathrm{aq}}$. An increase of $[\mathrm{Cr}]_{\mathrm{S}}$ is closely followed by a decrease in $[S]_{s}$. Analyses yielded similar $[\mathrm{Ca}]_{s}$ in all the solids.

XRD analyses confirm that precipitates exclusively consist of gypsum (Figure 6a), independent of $\left[\mathrm{CrO}_{4}{ }^{2-}\right]_{\mathrm{aq}}$ and $[\mathrm{Cr}]_{\mathrm{S}}$ (Powder Diffraction File, Inorganic, \#033-0311, International Center for Diffraction Data, Swarthmore, PA, USA). Moreover, a detailed study of the X-ray diffraction patterns of the precipitates reveals the existence of a clear and continuous shift of the most relevant gypsum diffraction peaks towards lower $2 \theta$ values as $[\mathrm{Cr}]_{\mathrm{S}}$ increases (see Table S1), as can be seen in Figure $6 \mathrm{~b}$ for the 
(020) reflection. Moreover, the relative intensities of the most important reflections also exhibit a continuous variation with respect to the amount of $\mathrm{Cr}$ in the solids (see values within parenthesis in Table S1). For instance, whereas the relative intensity of the (031) reflection gradually increases, the $(\overline{1} 22)$ reflection intensity clearly decreases as $[\mathrm{Cr}]_{\mathrm{s}}$ increases.
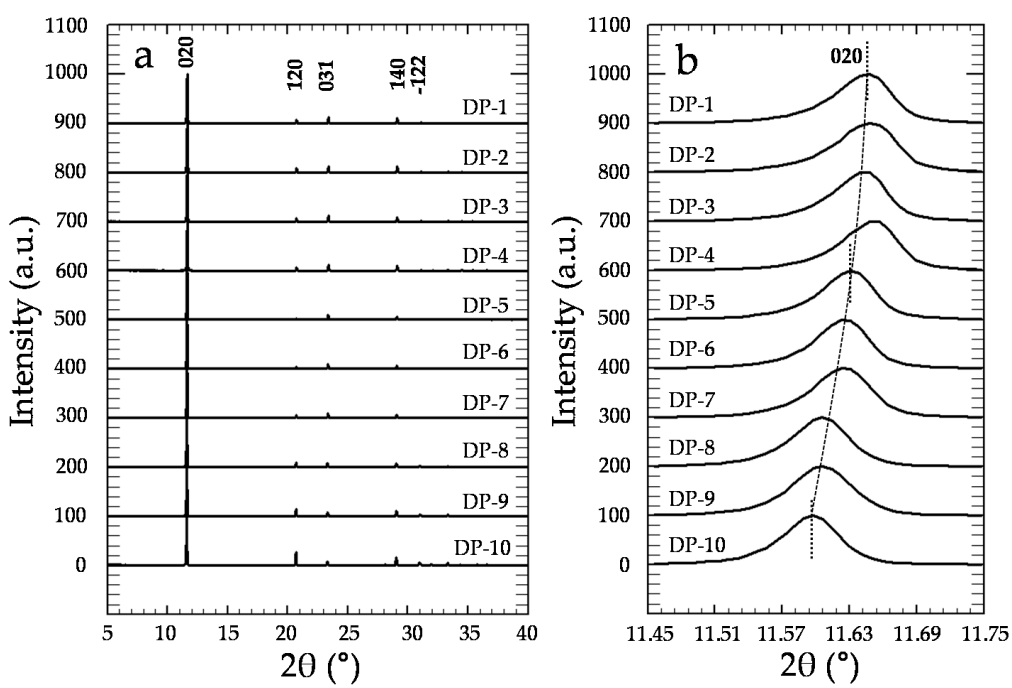

Figure 6. (a) Powder X-ray diffraction patterns of the precipitates. For the sake of clarity, all of the diffractograms have been normalized to the (010) peak, which is the most intense reflection; (b) Magnification of the (020) reflection, where a clear shift of this reflection towards lower $2 \theta$ values as $[\mathrm{Cr}]_{\text {aq }}$ increases can be observed.

The incorporation of small amounts of chromate in the solids causes a small but perceptible change in the cell parameters $\left(a_{0}, b_{0}, c_{0}\right)$ and the volume of the cell. As can be observed in Figure 7 , a linear and positive correlation between $[\mathrm{Cr}]_{\mathrm{s}}$ and these parameters can be established.
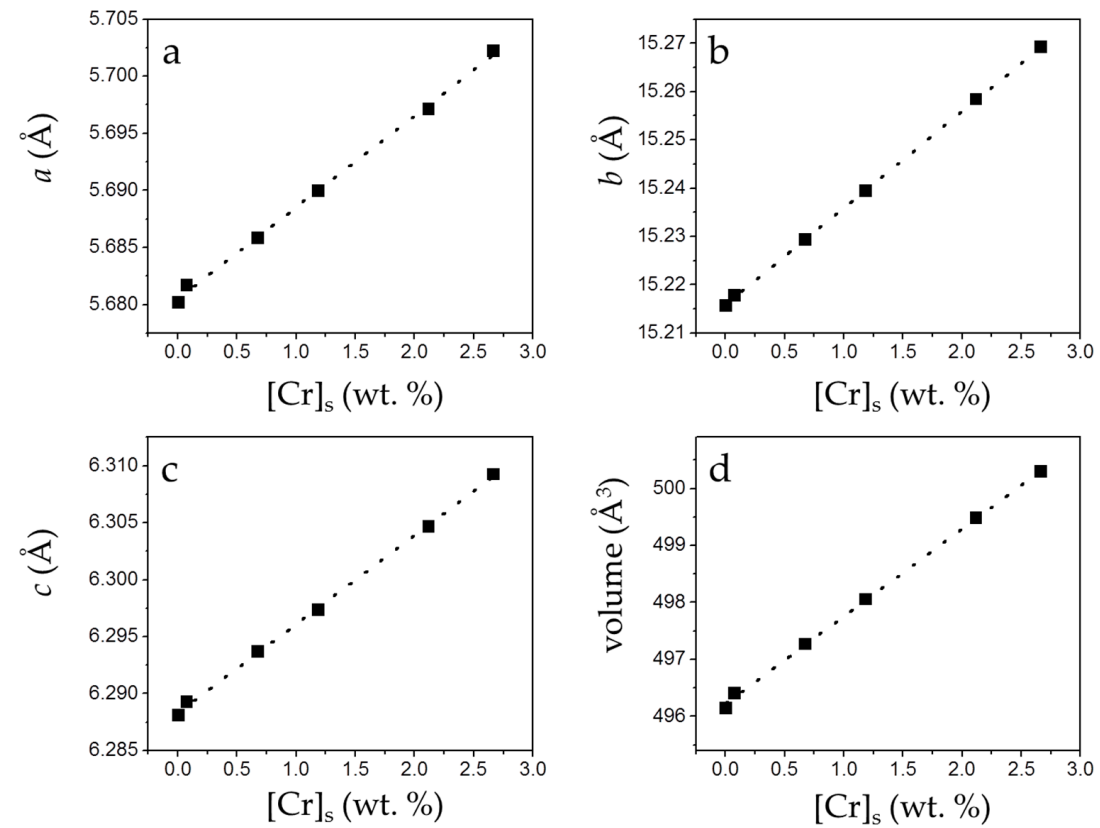

Figure 7. Unit cell parameters and cell volume (from the refinement of XRD patterns) of the precipitates plotted against $[\mathrm{Cr}]_{s}$. Cell parameters $(\mathbf{a}-\mathbf{c})$ and cell volume $(\mathbf{d})$ of gypsum increase as $[\mathrm{Cr}]_{\mathrm{s}}$ increases. 
Figure 8 shows the morphological characteristics of the precipitates grown in the absence and presence of different $\left[\mathrm{CrO}_{4}{ }^{2-}\right]_{\text {aq }}$. Gypsum crystals precipitated in the absence of chromate exhibit the typical needle-like habit and are elongated along the c-axis (15-30 $\mu \mathrm{m})$ (Figure 8a). However, those precipitates obtained from solutions containing higher amounts of chromate consist of less elongated needle-like crystals $(5-15 \mu \mathrm{m})$ and show a greater abundance of larger plate-like crystals with $\{010\}$ as the dominant form (Figure $8 b, c)$.
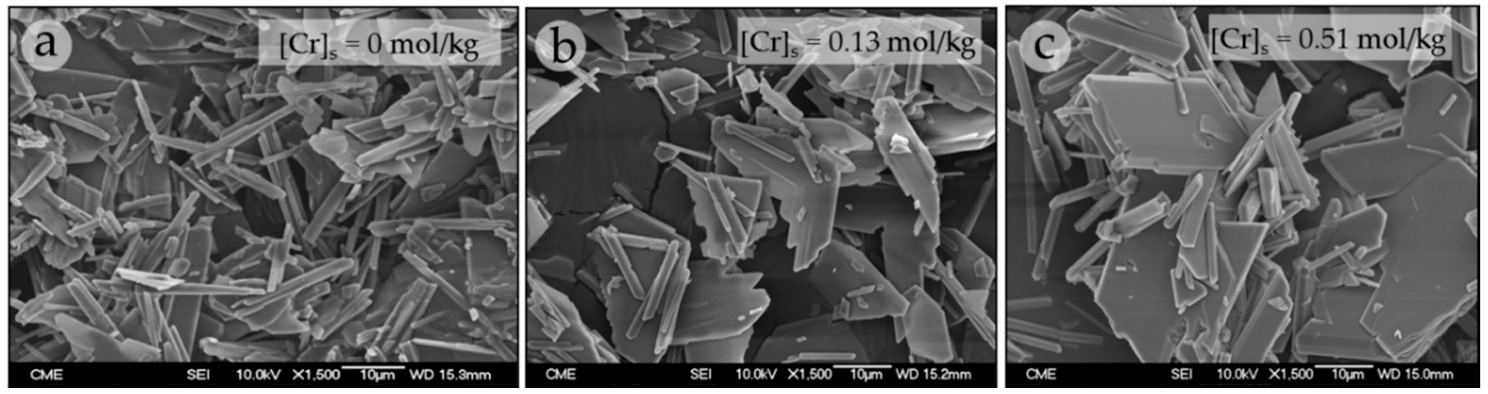

Figure 8. SEM micrographs of crystals collected in the precipitation experiments in the absence (a) and presence of different $\left[\mathrm{CrO}_{4}{ }^{2-}\right]_{\mathrm{aq}}: 0.1 \mathrm{M}(\mathbf{b})$; and $1 \mathrm{M}(\mathbf{c})$.

\section{Discussion}

In situ AFM observations of the growth of gypsum $\{010\}$ surfaces in the presence of chromate unequivocally show that this anion inhibits the growth of gypsum $\{010\}$ surfaces, affecting not only the step advancement rate but also the morphology of the growing steps. These observations can be interpreted in terms of the so-called "template effect", as defined by Astilleros et al. [2,8-11], who observed a similar inhibition-incorporation phenomenon during the growth of calcite surfaces in contact with supersaturated solutions bearing additives like $\mathrm{Mn}, \mathrm{Ba}, \mathrm{Mg}$ or Sr. The anomalous growth behavior of gypsum $\{010\}$ surfaces and the inhibiting effect on gypsum growth caused by the presence of chromate can only be satisfactorily explained by assuming the incorporation of this pollutant into the structure of this mineral phase. Indeed, the subtle variation of the color shade of the solids obtained from precipitation experiments can be regarded as a first indication that chromate is probably incorporated into the crystal structure of gypsum.

In the experiments carried out, such a sorption mechanism involves the trapping of chromate ions into the structure of gypsum during the precipitation of this phase, according to the reaction:

$$
\mathrm{SO}_{4}{ }^{2-}(\mathrm{aq})+\mathrm{CrO}_{4}{ }^{2-}(\mathrm{aq})+\mathrm{Ca}^{2+}(\mathrm{aq})+n \mathrm{H}_{2} \mathrm{O} \rightarrow \mathrm{Ca}\left(\mathrm{SO}_{4}, \mathrm{CrO}_{4}\right) \cdot 2 \mathrm{H}_{2} \mathrm{O}+(n-2) \mathrm{H}_{2} \mathrm{O}
$$

As highlighted in Figure 5, the net increase of $[\mathrm{Cr}]_{\mathrm{s}}(\sim 0.51 \mathrm{~mol} / \mathrm{kg})$ virtually equals the net decrease in $[S]_{\mathrm{S}}(\sim 0.53 \mathrm{~mol} / \mathrm{kg})$. Moreover, the total molalities of calcium and sulfate plus chromate are similar, clearly pointing to the existence of a substitutional solid solution between two end-members, $\mathrm{CaSO}_{4} \cdot 2 \mathrm{H}_{2} \mathrm{O}$ and a hypothetical, isostructural with gypsum $\mathrm{CaCrO}_{4} \cdot 2 \mathrm{H}_{2} \mathrm{O}$. In such a solid solution, $\mathrm{CrO}_{4}{ }^{2-}$ would substitute $\mathrm{SO}_{4}{ }^{2-}$ in the layered structure of gypsum. This assumption is additionally supported by the results of the XRD analysis. In all isomorphic substitutions, the difference in size between the substituting ions leads to an increase of the unit cell parameters as the concentration of the larger ion (chromate in the present case) increases in the crystal structure [28,29]. This is indirectly reflected by the shift towards lower $2 \theta$ values observed in specific, relevant peaks in the diffraction diagrams of the precipitates as $[\mathrm{Cr}]_{\mathrm{S}}$ in the solid increases (Figure $6 \mathrm{~b}$ and Table S1). Le Bail refinements also reveal the enlargement of the unit cell parameters and the expansion of the unit cell volume, which are most probably a consequence of the substitution of $\mathrm{SO}_{4}{ }^{2-}$ by $\mathrm{CrO}_{4}{ }^{2-}$. The plot of the refined cell parameters (Figure 7) shows a linear correlation between cell parameters and the amount of chromium present in the crystal lattice, in agreement with Vegard's Law [30]. 
When one anion substitutes another in a crystal structure, the amount of substitution depends to a great extent on the size and shape of the involved anionic groups. $\mathrm{CrO}_{4}{ }^{2-}$ and $\mathrm{SO}_{4}{ }^{2-}$ share a tetrahedron-like geometry and show a similar size. The isomorphic substitution of sulfate and chromate is not uncommon in mineral phases. For instance, the solid solution between barite $\left(\mathrm{BaSO}_{4}\right)$ and $\mathrm{BaCrO}_{4}$ is assumed to be ideal [31], which means that both phases are end-members of a complete solid solution [32]. Other sulfate minerals like ettringite [17,33] or jarosite [34] can also incorporate small amounts of $\mathrm{CrO}_{4}{ }^{2-}$ substituting $\mathrm{SO}_{4}{ }^{2-}$.

Although the similarity in the size and shape of two anions points to their isomorphic subtitution in a mineral structure as being possible, the degree of substitution and, therefore, the ability of a certain mineral to trap a foreign element via coprecipitation is the result of a variety of physico-chemical factors. One key factor is the difference of solubility between the end-members of the solid solution. In solid solution-aqueous solution (SS-AS) systems, distribution coefficients, D, are frequently used to express the partitioning of an ion between an aqueous solution and a solid phase. In the system considered here, the partition coefficient of $\left(\mathrm{CrO}_{4}{ }^{2-}\right)$ between the aqueous solution and the solid phase $\mathrm{Ca}\left(\mathrm{SO}_{4(1-x)} \mathrm{CrO}_{4(x)}\right) \cdot 2 \mathrm{H}_{2} \mathrm{O}$ can be defined by:

$$
\mathrm{D}_{\mathrm{CrO}_{4}{ }^{2-}}=\frac{\mathrm{X}_{\mathrm{CaCrO}_{4} \cdot 2 \mathrm{H}_{2} \mathrm{O}}}{X_{\mathrm{CaSO}_{4} \cdot 2 \mathrm{H}_{2} \mathrm{O}}} / \frac{a\left(\mathrm{CrO}_{4}{ }^{2-}\right)}{a\left(\mathrm{SO}_{4}{ }^{2-}\right)}
$$

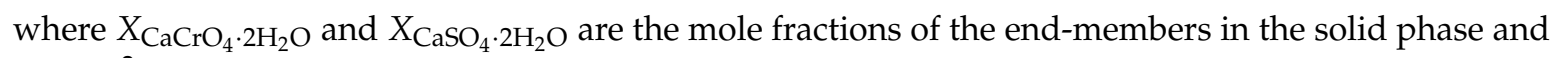
$a\left(\mathrm{CrO}_{4}{ }^{2-}\right)$ is the activity of chromate in the aqueous solution.

At thermodynamic equilibrium and assuming an ideal solid solution, the partition coefficient $\left(\mathrm{D}_{\text {eq }}\right)$ is defined by the ratio between the solubility product of gypsum and a calcium chromate dihydrate phase, isoestructural with the gypsum structure. Although the solubility of this phase is unknown, it should be necessarily higher than that of the stable form of the calcium chromate dihydrate, which is orthorhombic and over three orders of magnitude more soluble than gypsum. By considering this solubility, a maximum distribution coefficient $\mathrm{D}_{\mathrm{eq}}<0.001$ can be estimated. Such a small partition coefficient means that the tendency of the $\mathrm{CrO}_{4}{ }^{2-}$ ion to incorporate into the solid phase during the precipitation of a $\mathrm{Ca}\left(\mathrm{SO}_{4(1-x)} \mathrm{CrO}_{4(x)}\right) \cdot 2 \mathrm{H}_{2} \mathrm{O}$ solid solution is extremely low.

On the other hand, experimental studies have shown that the distribution coefficient also depends on kinetic factors, such as supersaturation levels, and that the "effective" distribution coefficients can largely differ from the equilibrium values. As has been profusely shown by Prieto et al. [35-37], at high supersaturations there is less chance for thermodynamically based selectivity effects to be exerted. For instance, Fernández-González et al. [32] studied the formation of the solid solution between $\mathrm{BaSO}_{4}$ and $\mathrm{BaCrO}_{4}$, showing that at high levels of supersaturation with respect to the less soluble end-member $\mathrm{BaSO}_{4}$, the effective distribution coefficients $\left(\mathrm{D}_{\text {eff }}\right)$ for $\mathrm{CrO}_{4}{ }^{2-}$ reached values very close to 1 , even though the $\mathrm{D}_{\text {eq }}=0.42$. In the system under consideration here the $\mathrm{D}_{\text {eff }}$ for $\mathrm{CrO}_{4}{ }^{2-}$ has a value $<0.05$. Although in this case this parameter is increased due to the effect of the high supersaturations used, a very marked preferential partitioning of $\mathrm{SO}_{4}{ }^{2-}$ towards the solid phase still occurs.

The results obtained in the precipitation experiments indicate that the presence of chromate in the aqueous solution exerts an important role in the precipitation process of gypsum. This effect is revealed by both the lengthening of $\mathrm{t}_{\mathrm{w}}$ and a decrease of the amount of recovered precipitate as $\left[\mathrm{CrO}_{4}{ }^{2-}\right]_{\mathrm{aq}}$ increases. These results clearly point to an inhibitory effect of chromate on the nucleation of gypsum. This effect is also supported by the SEM images, which clearly reveal changes in both size and habit of the gypsum crystals. The larger size of the crystals formed in the presence of increasing amounts of chromate is consistent with moderate kinetics of nucleation which, in turn, can only be ascribed to an inhibitory effect of this anion, since the supersaturation with respect to gypsum was similar in all the experiments. Indeed, according to the nucleation theory ([20], and references therein), smaller and numerous crystals are frequently the result of catastrophic nucleation events, whereas scarcer and larger crystals are formed under nucleation-restricted conditions. On the other hand, changes in 
crystal habit are also frequently explained by a selective sorption of the additive on certain faces of a crystal. When this is the case, the inhibitory effect is more intense on those specific faces, which will grow more slowly. The resulting effect is the modification of the crystal habit. In the gypsum crystals, the transition from crystals with a needle-like habit elongated along the c-axis to plate-like crystals with $\{010\}$ as the dominant form could be tentatively explained by a selective sorption of $\mathrm{CrO}_{4}{ }^{2-}$ on specific gypsum surfaces.

Finally, the results demonstrate that although gypsum can incorporate chromate into its structure, the substitution of $\mathrm{SO}_{4}{ }^{2-}$ by $\mathrm{CrO}_{4}{ }^{2-}$ in the gypsum structure detected in the precipitates reaches a maximum value as low as $\sim 8 \%$, even under the most favorable physicochemical conditions for $\mathrm{CrO}_{4}{ }^{2-}$ incorporation (high supersaturation with respect to gypsum and high concentration of chromate in the solution). Such conditions are far from those prevailing in natural environments and, consequently, coprecipitation with gypsum cannot be regarded as an effective method for the removal of chromate from soil and groundwaters. Other sulfate minerals like barite have proved to be much more effective at chromate sequestration. This said, it is important to keep in mind that gypsum is a very abundant a mineral, at any rate much more abundant than barite, and as pointed out by Prieto et al. (2013) [37] for aqueous solution-solid solution reactions, the equilibrium end-point depends on the specific initial amounts of solid and liquid as well as the solubility of the respective end-members and the degree of ideality of the solid solution.

Supplementary Materials: The following are available online at www.mdpi.com/2075-163X/6/1/22/s1, Table S1: Position and relative intensities (in parenthesis) of the main reflections in the XRD patterns collected from the samples.

Acknowledgments: This research was funded by project CGL2013-47988-C2-1-P (Ministerio de Economía y Competitividad; MINECO-Spain). Juan Morales acknowledges an FPI (Formación de Personal Investigador) fellowship from the Spanish Ministry of Science and Innovation. The authors wish to thank the National Centre of Microscopy (ICTS-CNME, UCM), the X-ray Diffraction Central Service and the Geological Techniques Research Centre of the Complutense University of Madrid (UCM) for kindly providing technical support for their research.

Author Contributions: Juan Morales, José Manuel Astilleros and Lurdes Fernández-Díaz contributed to the conception of the study; Juan Morales and José Manuel Astilleros performed the laboratory experiments; Juan Morales and Emilio Matesanz were responsible for the XRD analyses; all authors analyzed the data; Juan Morales, José Manuel Astilleros and Lurdes Fernández-Díaz were involved in the manuscript preparation. All authors read and approved the manuscript.

Conflicts of Interest: The authors declare no conflict of interest.

\section{References}

1. Davis, K.J.; Dove, P.M.; de Yoreo, J.J. The role of $\mathrm{Mg}^{2+}$ as an impurity in calcite growth. Science 2000, 290, 1134-1137. [CrossRef] [PubMed]

2. Astilleros, J.M.; Pina, M.; Fernández-Díaz, L.; Putnis, A. Nanoscale growth of solids crystallising from multicomponent aqueous solutions. Surf. Sci. 2003, 545, L767-L773. [CrossRef]

3. Shtukenberg, A.G.; Astilleros, J.M.; Putnis, A. Nanoscale observations of epitaxial growth of hashemite on barite (001). Surf. Sci. 2005, 590, 212-223. [CrossRef]

4. Astilleros, J.M.; Pina, M.; Fernández-Díaz, L.; Prieto, M.; Putnis, A. Nanoscale phenomena during the growth of solid solutions on calcite $\{10 \overline{1} 4\}$ surfaces. Chem. Geol. 2006, 225, 322-335. [CrossRef]

5. Vavouraki, A.I.; Putnis, C.V.; Putnis, A.; Koutsoukos, P.G. An Atomic Force Microscopy study of the growth of calcite in the presence of sodium sulfate. Chem. Geol. 2008, 253, 243-251. [CrossRef]

6. Sethmann, I.; Wang, J.; Becker, U.; Putnis, A. Strain-induced segmentation of magnesian calcite thin films growing on a calcite substrate. Cryst. Growth Des. 2010, 10, 4319-4326. [CrossRef]

7. Nielsen, L.C.; de Yoreo, J.J.; de Paolo, D.J. General model for calcite growth kinetics in the presence of impurity ions. Geochim. Cosmochim. Acta 2013, 115, 100-114. [CrossRef]

8. Astilleros, J.M. Estudio Integrado de la Cristalización de Soluciones Sólidas no Ideales: $(\mathrm{Ca}, \mathrm{M}) \mathrm{CO}_{3}(\mathrm{M}=\mathrm{Ba}$, Sr, Mn). Ph.D. Thesis, Universidad Complutense de Madrid, Madrid, Spain, 2001. (In Spanish)

9. Astilleros, J.M.; Pina, C.M.; Fernández-Díaz, L.; Putnis, A. Molecular scale surface processes during the growth of calcite in the presence of manganese. Geochim. Cosmochim. Acta 2002, 66, 3177-3189. [CrossRef] 
10. Astilleros, J.M.; Pina, C.M.; Fernández-Díaz, L.; Putnis, A. Metastable phenomena on calcite $\{10 \overline{1} 4\}$ surfaces growing from $\mathrm{Sr}^{2+}-\mathrm{Ca}^{2+}-\mathrm{CO}_{3}{ }^{2-}$ aqueous solutions. Chem. Geol. 2003, 193, 93-107. [CrossRef]

11. Astilleros, J.M.; Fernández-Díaz, L.; Putnis, A. The role of magnesium in the growth of calcite: An AFM study. Chem. Geol. 2010, 271, 52-58. [CrossRef]

12. Freij, S.J.; Putnis, A.; Astilleros, J.M. Nanoscale observations of the effect of cobalt on calcite growth and dissolution. J. Cryst. Growth 2004, 267, 288-300. [CrossRef]

13. Sánchez-Pastor, N.; Pina, C.M.; Fernández-Díaz, L.; Astilleros, J.M. The effect of $\mathrm{CO}_{3}{ }^{2-}$ on the growth of barite $\{001\}$ and $\{210\}$ surfaces: An AFM study. Surf. Sci. 2006, 600, 1369-1381. [CrossRef]

14. Ruiz-Agudo, E.; Putnis, C.V.; Kowacz, M.; Ortega-Huertas, M.; Putnis, A. Boron incorporation into calcite during growth: Implications for the use of boron in carbonates as a $\mathrm{pH}$ proxy. Earth Planet. Sci. Lett. 2012, 345-348, 9-17. [CrossRef]

15. Nriagu, J.O.; Nieboer, E. Chromium in the Natural and Human Environments; John Wiley \& Sons: New York, NY, USA, 1988.

16. Parkhurst, D.L.; Appelo, C.A.J. User's Guide to PHREEQC (Version 2): A Computer Program for Speciation, Batch-Reaction, One-Dimensional Transport and Inverse Geochemical Calculations: U.S. Geological Survey Water Resources Investigations Report 99-4259; U.S. Geological Survey: Denver, CO, USA, 1999.

17. Perkins, R.B.; Palmer, C.D. Solubility of $\mathrm{Ca}_{6}\left[\mathrm{Al}(\mathrm{OH})_{6}\right]_{2}\left(\mathrm{CrO}_{4}\right)_{3} \cdot 26 \mathrm{H}_{2} \mathrm{O}$, the chromate analogue of ettringite; 5-75 ${ }^{\circ}$ C. Appl. Geochem. 2000, 15, 1203-1218. [CrossRef]

18. Kostov, L.; Kostov, R.I. Crystal Habits of Minerals; Bulgarian Academic Monographs; Pensoft Publishers: Sofia, Bulgaria, 1999; pp. 308-310.

19. Morales, J.; Astilleros, J.M.; Fernández-Díaz, L. Nanoscopic characteristics of anhydrite (100) growth. Cryst. Growth Des. 2012, 12, 414-421. [CrossRef]

20. Söhnel, O.; Mullin, J.W. Interpretation of crystallization induction periods. J. Colloid Interface Sci. 1988, 123, 43-50. [CrossRef]

21. Söhnel, O.; Mullin, J.W. A method for the determination of precipitation induction periods. J. Cryst. Growth 1978, 44, 377-382. [CrossRef]

22. Le Bail, A.; Duroy, H.; Fourquet, J.L. Ab initio structure determination of $\mathrm{LiSbWO}_{6}$ by X-ray powder diffraction. Mater. Res. Bull. 1988, 23, 447-452. [CrossRef]

23. Rodríguez-Carvajal, J. Recent advances in magnetic structure determination by neutron powder diffraction. Phys. B Condens. Matter 1993, 192, 55-69. [CrossRef]

24. Comodi, P.; Nazzareni, S.; Zanazzi, P.F.; Speziale, S. High-pressure behavior of gypsum: A single-crystal X-ray study. Am. Mineral. 2008, 93, 1530-1537. [CrossRef]

25. Thompson, P.; Cox, D.E.; Hastings, J.B. Rietveld refinement of Debye-Scherrer synchrotron X-ray data from $\mathrm{Al}_{2} \mathrm{O}_{3}$. J. Appl. Crystallogr. 1987, 20, 79-83. [CrossRef]

26. Finger, L.W.; Cox, D.E.; Jephcoat, A.P. A correction for powder diffraction peak asymmetry due to axial divergence. J. Appl. Cryst. 1994, 27, 892-900. [CrossRef]

27. Van Driessche, A.E.S.; García-Ruiz, J.M.; Delgado-López, J.M.; Sazaki, G. In situ observation of step dynamics on gypsum crystals. Cryst. Growth Des. 2010, 10, 3909-3916. [CrossRef]

28. Hawthorne, F.C.; Krivovichev, S.V.; Burns, P.C. The crystal chemistry of sulfate minerals. In Sulfate Minerals Crystallography, Geochemistry, and Environmental Significance. Reviews in Mineralogy E Geochemistry; Alpers, C.N., Jambor, J.L., Nordstrom, D.K., Eds.; Mineralogical Society of America and Geochemical Society: Washington, DC, USA, 2000; Volume 40, pp. 1-112.

29. Casari, B.M.; Eriksson, A.K.; Langer, V. Synthesis methods for $\mathrm{Ce}\left(\mathrm{CrO}_{4}\right)_{2} \cdot x \mathrm{H}_{2} \mathrm{O}$ and crystal structures of $\mathrm{K}_{2} \mathrm{CrSO}_{7},\left(\mathrm{NH}_{4}\right)_{2} \mathrm{Cr}_{2} \mathrm{O}_{7}$ and $\mathrm{Na}_{2} \mathrm{Cr}_{2} \mathrm{O}_{7} \cdot 2 \mathrm{H}_{2} \mathrm{O}$. Z. Naturforsch. B 2007, 62, 771-777. [CrossRef]

30. Vegard, L. Die Konstitution der Mischkristalle und die Raumfüllung der Atome. Z. Phys. 1921, 5, 17-26. (In German) [CrossRef]

31. Glynn, P.D.; Reardon, E.J.; Plummer, L.N.; Busenberg, E. Reaction paths and equilibrium end-points in solid-solution aqueous-solution systems. Geochim. Cosmochim. Acta 1990, 54, 267-282. [CrossRef]

32. Fernández-González, A.; Martín-Díaz, R.; Prieto, M. Crystallisation of $\mathrm{Ba}\left(\mathrm{SO}_{4}, \mathrm{CrO}_{4}\right)$ solid solutions from aqueous solutions. J. Crys. Growth 1999, 200, 227-235. [CrossRef]

33. Leisinger, S.M.; Lothenbach, B.; Saout, G.L.; Kägi, R.; Wehrli, B.; Johnson, C.A. Solid solutions between $\mathrm{CrO}_{4}{ }^{-}$ and $\mathrm{SO}_{4}$-ettringite $\mathrm{Ca}_{6}\left(\mathrm{Al}(\mathrm{OH})_{6}\right)_{2}\left[\left(\mathrm{CrO}_{4}\right)_{x}\left(\mathrm{SO}_{4}\right)_{1-x}\right]_{3} \cdot 26 \mathrm{H}_{2} \mathrm{O}$. Environ. Sci. Technol. 2010, 44, 8983-8988. [CrossRef] [PubMed] 
34. Baron, D.; Palmer, C.D. Solid-solution aqueous-solution reactions between jarosite $\left(\mathrm{KFe}_{3}\left(\mathrm{SO}_{4}\right)_{2}(\mathrm{OH})_{6}\right)$ and its chromate analogue. Geochim. Cosmochim. Acta 2002, 66, 2841-2853. [CrossRef]

35. Prieto, M.; Fernández-González, A.; Putnis, A.; Fernández-Díaz, L. Nucleation, growth, and zoning phenomena in crystallizing $(\mathrm{Ba}, \mathrm{Sr}) \mathrm{CO}_{3}, \mathrm{Ba}\left(\mathrm{SO}_{4}, \mathrm{CrO}_{4}\right),(\mathrm{Ba}, \mathrm{Sr}) \mathrm{SO}_{4}$, and $(\mathrm{Cd}, \mathrm{Ca}) \mathrm{CO}_{3}$ solid solutions from aqueous solutions. Geochim. Cosmochim. Acta 1997, 61, 3383-3397. [CrossRef]

36. Prieto, M.; Fernández-González, A.; Martín-Díaz, R. Sorption of chromate ions diffusing through barite-hydrogel composites: Implications for the fate and transport of chromium in the environment. Geochim. Cosmochim. Acta 2002, 66, 783-795. [CrossRef]

37. Prieto, M.; Astilleros, J.M.; Fernández-Díaz, L. Environmental remediation by crystallization of solid solutions. Elements 2013, 9, 195-201. [CrossRef]

(C) 2016 by the authors; licensee MDPI, Basel, Switzerland. This article is an open access article distributed under the terms and conditions of the Creative Commons by Attribution (CC-BY) license (http://creativecommons.org/licenses/by/4.0/). 